E-Journal of Tourism Vol.8. No.1. (2021): 115-124

\title{
E-Tourism as A Promotion Media for Cimande Tourism Village
}

\author{
Dhanik Puspita Sari*, Rima Pratiwi Batubara \\ Sekolah Tinggi Pariwisata Bogor, Indonesia \\ *Corresponding Author: puspitasaridhanik@gmail.com \\ DOI: https://doi.org/10.24922/eot.v8i1.71452
}

\section{Article Info}

Submitted

December $4^{\text {th }} 2020$

Accepted

March $18^{\text {th }} 2021$

Published

March $31^{\text {th }} 2021$

\begin{abstract}
Cimande Tourism Village promotion is done to provide information to potential visitors about the tourism potential in the region. Promotion using the website (e-tourism) is believed to convey information more clearly and widely. This research was conducted in Cimande Tourism Village, in Caringin District, Bogor Regency. Research uses qualitative descriptive methods. The research object is Cimande tourism village website's with access desawisatacimande.com. The result discover that Cimande tourism village website has a fairly good level of visibility by using search engines namely Google, Yahoo and Bing. Promotional techniques are carried out by linking information related to tourism, namely information about the activities of Cimande Tourism Village itself. Online public relations not yet available. The websites email are available even though they are still minimal in use. The manager has not recorded the visitors so the ranking related to the visitor does not exist. Therefore, the author recommends that managers work together with other institutions to meet human resources needs in order to improving knowledge and skills related to the promotion, especially for websites. In addition, the manager can also ask the relevant institutions to cooperate in the promotion activities of Cimande Tourism Village.
\end{abstract}

Keywords: promotion, e-tourism, website, tourism village, Cimande

\section{INTRODUCTION}

The Village tourism is a form of community-based tourism activity. This type of tourism is being relentlessly carried out given the multiplier effect that can be directly felt by the community, especially in the form of economy. One of the tourist villages that is being developed is Cimande Tourism Village. The location is not so far from the capital city of Jakarta and the ease of accessibility becomes an advantage for this tourist village.

Marketing is the spearhead of the number of consumers (in this case tourists) who come to visit and spend time and expenses in an area. One of the purposes of this is to be able to convey or provide information to the public about a product or tourist attraction that of course is expected to attract tourists to visit. If the information needs have been met then the satisfaction of tourists can also be met (Anshar and Batubara, 2019).

The number of forms of promotion is not a benchmark for the success of a marketing activity. Choosing the right media according to the characteristics and beha- 
vior of the market segment is important. Continuous modernization requires that the promotional forms placed through the right media are placed through the right media.

E-tourism is one form of media or promotional tool on the rise now. The ease of accessing information through the internet as well as the increasing use of social media coupled with the large number of internet users in Indonesia makes this promotional media very useful. The existence of the website is very important to be developed in Cimande Tourism Village. With the website, the manager can develop his tourism potential more widely and quickly (Batubara, 2020). Therefore, research needs to be done to find out the promotional activities carried out by the manager of Cimande Tourism Village. In addition, to be aware of the condition of the website used as a promotional medium by Cimande tourism village. This is done in order to know the suitability of e-tourism that will be used Cimande tourism village.

\section{LITERATURE REVIEW}

\section{Village Tourism}

Village tourism is one form of application of community-based and sustainable tourism development. Tourist villages as a form of rural tourism can provide many benefits to the development efforts of various resources owned by rural areas (Sugiarti, 2008). The development of tourist villages can have a positive impact on the villagers themselves, such as the new employment land for the community so as to lower the unemployment rate in the village. In addition, the tourism village that carries the concept of ecotourism will make a village able to maintain the sustainability of nature and culture of the village. Another thing is, a tourist village can make a village into an independent village because it can provide alternative jobs that can be entered by the local community.

http://ojs.unud.ac.id/index.php/eot
Related to the concept of tourism village development, Pearce (1995) interprets the development of tourist villages as a process that emphasizes ways to develop or advance tourist villages. More specifically, the development of tourist villages is interpreted as efforts to equip and improve tourist facilities to meet the needs of tourists. Rural tourism is a tourism consisting of a whole rural experience, natural attractions, traditions, unique elements that can overall attract tourists (Joshi, 2012), and every tourist must have different motivations and desires between one and the other which makes their motivation background in determining where to do tourist activities (Sari, 2019).

\section{Promotion}

Promotion is any form of communication used by the company to inform, persuade, or remind people of the products, services, shadows, ideas or involvement of the company and the public with the intent to accept and perform the actions as desired by the company (Sigit in Wardana, 2015). What a company or business entity wants is the sale of products that they own in the form of goods or services so that they can benefit in the form of economic benefits.

The economic benefits that will be gained of course come from the spending made by tourists during their visit and spending time in the destination of tourism, the higher the amount of money spent, it will automatically impact the increase in income from the tourism sector of a region (Sari, 2018).

Promotion is a process of introducing products to consumers in an interesting way. The promotion is included in marketing that has the principle of communication to attract the public's interest in the objects offered. The purpose of the promotion is to influence and inform the public that there are products offered (Marpaung and Bahar, 2002). To be able to attract tourists 
is by displaying the tourist activities that have, without the activity will not be able to attract tourists to be able to visit (Sari, 2017).

Thus the promotion of tourism is an effort made by the tourists to be able to attract the attention of tourists by putting together a tourism product that is appropriate to be sold to tourists. A form of tourism promotion activity is carried out in a relatively short time by prioritizing activities for the main purpose of increasing the appeal of tourist products to prospective tourists.

\section{Promotion Media}

Media is one of the containers of distribution of works so that it can be seen and felt by consumers. Media can be interpreted as a supporting tool to conduct an activity. Promotion is an effort to tailor travel products to the demand of tourism, so that the products offered become more attractive. Tourism promotion activities can be done through various media such as print and electronic media. Promotional media that can be used are leaflets, booklets, catalogs, videos, advertisements, newspapers and others (Marpaung and Bahar, 2002) and promotions are one of the four basic elements of marketing on the website (Stankov, Curčić and Dragićević, 2010).

The official website of a destination is one of the important elements that is now attached to the destination itself. The use of the internet is massif, making the relationship between tourism and the internet as one of the promotional media platforms. Promotional media is created to influence consumers to buy products offered and packaged in such a way as to look perfect.

The advantage of using electronic media in the form of a website for a travel agent is that they can display images and videos from almost any destination in the world (Stankov, Ćurčić and Dragićević, 2010), the hotel can display the rooms it has, as well as the utilization of the website for promotional activities of a destination, the tour destination manager can display images of all the resources it has.

In promotional media in the form of websites, the basic use and level of use of the destination's official website is a mustnote. In detail, which should be considered more observantly in the form of domain name (adequacy of domain name, adequate TDL, existence of country code), basic year of website site, website type, credibility and functionality of website site (website owner existence, copyright and data quotation, update), quality of content presentation (navigation - menu bar in all website sites, navigation function, quick search and sitemap-, color contrast, availability of foreign languages), visibility and search engine devices, internet promotion techniques (the presence of links, link structure (travel and tourism sectors, non tourism sector, banner presence), online PR (news section, chat, forums, online polling), the presence of email marketing elements, the presence of ratings - based on the number of visitors and the region of the ranking of origin, country) (Stankov, Ćurčić and Dragićević, 2010).

\section{E-Tourism}

E-tourism is a form of travel recommendation, but it can also be in the form of an application that can help to organize and organize the user's travel (Sebastia et al., 2009). The Minister of Tourism at the opening of the Cultural Festival in Bali pointed out that e-tourism is a digital platform that connects all tourism stakeholders, facilitates the licensing process, integrates all tourism activities and provides convenience for all tourists exploring the charms of Indonesia through an easy-to-use app, anytime and anywhere (Noviyanti, 2014).

Every tourist destination, including Cimande Tourism Village certainly competes with other similar tourist destinations in an effort to attract tourists to visit, and e-ISSN 2407-392X. p-ISSN 2541-0857 
can reach all layers of community with the most minimal obstacles, therefore the use of means of communication and promotion such as official website is very important (Fernández-Cavia et al., 2014). The official website of a destination can also be used to provide accurate information and have several advantages and advantages. Excellence content in travel services is an important strategy in an e-tourism web design to attract tourists (Ku and Chen, 2015).

In order to provide clarity of information and promotion of e-tourism in the form of a website, the official tourist destination, then there must be some important aspects that must be fulfilled. On any website must include several aspects, namely: 1) technical aspects (homepage, ease of use and access, and positioning), 2) communicative aspects (number of content or selection and use of language, 3 ) relational aspects (interactivity, social web, mobile communication), and 4) persuasive aspects (marketing, branding, discourse analysis) (FernándezCavia et al., 2014).

\section{METHODS}

This research was conducted in $\mathrm{Ci}$ mande Tourism Village, Caringin District, Bogor Regency. Cimande Tourism Village is located between two hills of Mount Pangrango and Mount Salak. The area \pm 335 Ha with an altitude of $550 \mathrm{Mdpl}$.

The technique used to analyze is a descriptive technique, i.e. all collected data is analyzed and searched for common thread with theories available so that it can interpret and draw conclusions based on the description of answers given by the source about the activities, media and messages stated in the promotion. Primary data is taken from tour participants, local governments and local communities, while secondary data is obtained through literature studies, past research and others. Data collection is done with observations, inter- views, documentation and litelature study.

The technique used to analyze is a descriptive technique, i.e. all collected data is analyzed and searched for common thread with theories available so that it can interpret and draw conclusions based on the description of answers given by the source about the activities, media and messages stated in the promotion. Primary data is taken from tour participants, local governments and local communities, while secondary data is obtained through literature studies, past research and others. Data collection is done with observations, interviews, documentation and library searches. Here are the indicators used in the study (Table 1).

\section{RESULTS AND DISCUSSION}

Promotion is a marketing tool with the aim of informing, reminding, providing information and persuading to buy. In order to achieve it all then the promotional mix can be done. Promotional mix of advertising, sales promotion, personal sales, public relations and publicity and direct marketing.

Cimande Tourism Village conducted several promotional mixes to introduce the area to a wide audience. Promotion in the form of public relations and publicity and direct marketing. In public relations and publicity activities, the media used and its form is in the form of press releases and digital publications. As for talk shows have not been done. The second promotional activity is by doing direct marketing. The form or media used in this direct marketing activity is through online marketing by using internet-based media such as the use of social media and the official website of Cimande Tourism Village (Table 2). Both forms of promotion were chosen on the grounds of its wide reach without limits, as well as the lack of costs incurred. 
Table 1. Research indicators

\begin{tabular}{|c|c|c|}
\hline Dimension & Indicator & Criteria \\
\hline $\begin{array}{l}\text { Visibility and search rank- } \\
\text { ing engines }\end{array}$ & $\begin{array}{l}\text { Visibility and } \\
\text { search ranking } \\
\text { engines }\end{array}$ & Available / Not avaliable / Rank \\
\hline $\begin{array}{l}\text { Promotional techniques via } \\
\text { internet }\end{array}$ & $\begin{array}{l}\text { Links } \\
\text { Link's structure }\end{array}$ & $\begin{array}{l}\text { Available / Not avaliable / Number } \\
\text { Tourism and travel Sector / non- } \\
\text { Tourism and travel Sector }\end{array}$ \\
\hline Online PR & $\begin{array}{l}\text { Banners } \\
\text { (News section) } \\
\text { (Chat forum) } \\
\text { Online Poll }\end{array}$ & $\begin{array}{l}\text { Available / Not avaliable / Number } \\
\text { Available / Nonavaliable } \\
\text { Available / Not avaliable } \\
\text { Available / Not avaliable }\end{array}$ \\
\hline Marketing email & Marketing email & Available / Not avaliable \\
\hline $\begin{array}{l}\text { Rangking (by number of } \\
\text { visitor) }\end{array}$ & number of visitor & Rangking / country \\
\hline
\end{tabular}

Source: Stankov, Ćurčić and Dragićević (2010)

Table 2.Cimande Tourism Village promotion activities

\begin{tabular}{lcc}
\hline Promotion mix & Avaliable & Not avaliable \\
\hline Advertising & & \\
$\begin{array}{l}\text { a. Print Newspapers, magazines, tabloids, brochures, pam- } \\
\text { phlets, posters }\end{array}$ & $\sqrt{ }$ \\
$\begin{array}{l}\text { b. Electronic } \\
\text { Television, radio, internet }\end{array}$ & $\sqrt{ }$ \\
$\begin{array}{l}\text { Sales Promotion } \\
\text { Sampel, coupon, cash back, package price, prize, contest, } \\
\text { sweepstakes, game, subscription rewards, free testing, } \\
\text { product warranty }\end{array}$ & \\
$\begin{array}{l}\text { Public relation and publicity } \\
\text { Press releases, digital publications, talkshows }\end{array}$ & $\sqrt{ }$ \\
$\begin{array}{l}\text { Personal selling } \\
\text { Field selling, retail, executive selling }\end{array}$ & $\checkmark$ \\
$\begin{array}{l}\text { Direct marketing, } \\
\text { Direct mail marketing, catalog marketing (online), telemar- } \\
\text { keting, direct response television (DRTV) marketing, kiosk } \\
\text { marketing, online marketing. }\end{array}$ & \\
\hline
\end{tabular}

Source: Data Research, 2020

Cimande Tourism Village website December 27, 2019 and will end on Dehas a domain name desawisatacimande. cember 27, 2020.

com. This name is selected because it is As a representation of the form of econsidered memorable by the user. Ciman- tourism, the official website of Cimande de Tourism Village website was created on Tourism Village must and should have ruhttp://ojs.unud.ac.id/index.php/eot 
les or meet the standard criteria of a website. Stankov, Ćurčić and Dragićević (2010) explained that there are at least a few things to note in the creation of the website including visibility and ranking of search engines, promotion techniques through the internet, online public relations, and elements of e-mail marketing as well as ranking / order of visitors.

\section{Visibility and Search Engine}

Visibility in the website is the visibility of the site on search engines (Handayani, Febriyanto and Shofwatullah, 2019). This visibility should and should be optimized to achieve the level of website user visits desired by the tour village website manager. The visibility of a site is influenced by factors such as keywords and search engines used. Cimande Tourism Village website has a fairly good level of visibility. With the keyword "Cimande Tourism Village" then at least Cimande tourism village website how many on the 5 largest searches.

The search engines used in the author's observations are Google, Yahoo and Bing. The determination of this search engine is considered a frequent use by tourists. On Google search engines, Cimande tourism village website is ranked 16 th and is found on the second page of the search engine (Figure $\mathrm{x}$ ). Thus it can be known that Cimande tourism village website search on Google search engine is considered bad. This is due to the lack of updates made by the website manager as well as the lack of information provided by the website manager so that internet users prefer to search for regional information to other websites.

On Yahoo and Bing search engines, The Cimande Tourism Village website is in first place. Website rankings on a search engine may vary due to several factors. The ranking factor of a website in search engines is influenced by the algorithm of website ranking, search activity, websites visited up to the device used (Andri, 2009; Santoso, 2009). This is because each search engine records all search traces performed by the user of the device so that later when the user searches for an information will always be associated with information related to the previous information.

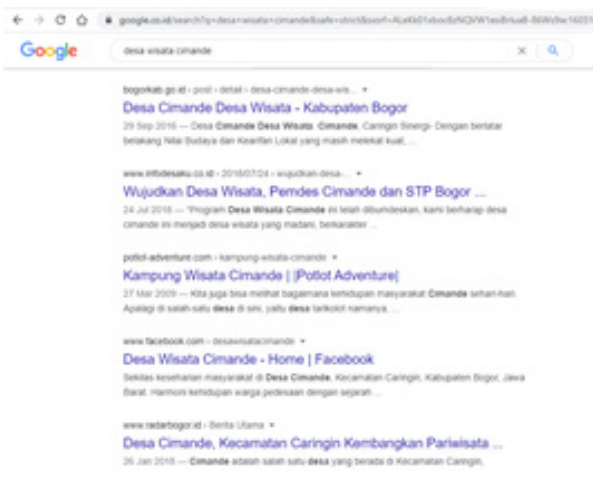

Figure 1. Search engine by Google

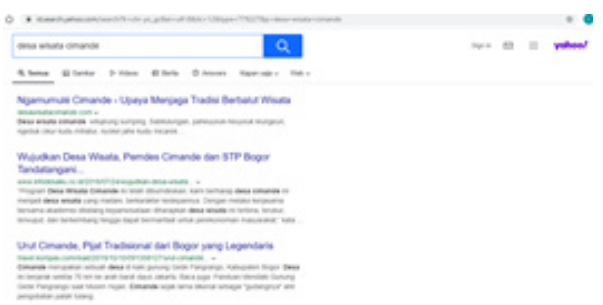

Figure 2. Search engine by Yahoo

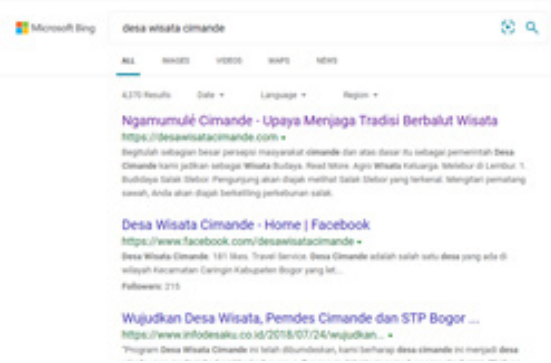

Figure 3. Search engine by Bing

Basically a lot of ways are done so that website managers can put their website at the top of the rankings. In Handayani, Febriyanto and Shofwatullah (2019) revealed that the implementation of Search Engine Optimization (SEO) can improve search engine results pages (SERP) websites in search engines, the volume and quality of traffic visits from google search engines by 
up to 70 percent. Search Engine Optimization (SEO) is a systematically performed technique and process to optimize website visibility or visibility. This technique aims to increase the number of visits to a website by utilizing search engine algorithms.

\section{Internet Promotion Techniques Links}

Links or links are an important component of a website. The link on serves to connect a page to another website page. On Cimande tourism village website, the link found is in the form of writing. The link on Cimande tourism village website is so that different information themes or discussions can be placed neatly (not mixed) making it easier for the reader to understand the information provided.

The type of link used on cimande tourism village website consists of two internal links and external links. Internal links are used to connect pages to each other in one website or domain. Internal links can be found on the first page of the website with the title "Cimande is not Just Silat and Fracture". On the first page is shown only a little information from the article that is on another page of the website. The internal link is in the form of the word "Next". When the website visitor clicks on the article, it will be linked to the information on the other website page that is about the article (the article "Cimande is not Just Silat and Fracture") in the full version.

As for external links, it is used to open another web or domain. External use of links can be found on the first page which is the emblem of Facebook and Instagram. When this symbol is clicked it will be linked on social media.

\section{Link's structure}

Cimande Tourism Village website has a hierarchy-shaped link structure. The hierarchy structure can be imagined as the organizational structure of a society. The

http://ojs.unud.ac.id/index.php/eot hierarchy structure is used to connect the pages on the website. Thus the explanation related to the link is an explanation about the tour in Cimande Village itself.

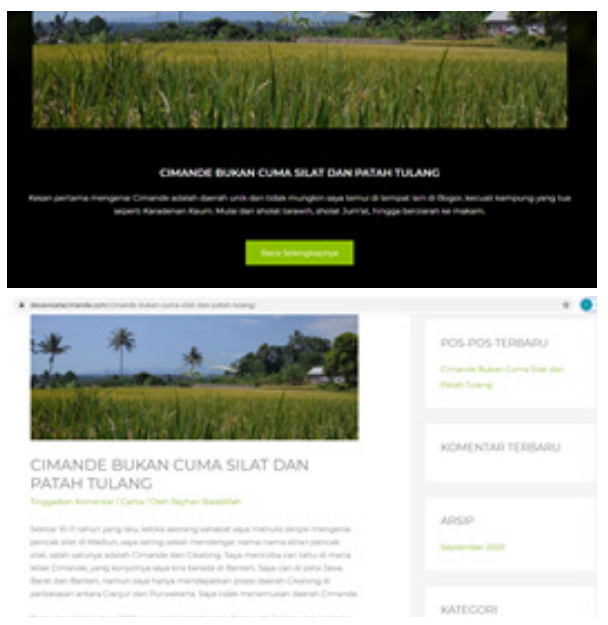

Figure 4. Links on the website (internal links)

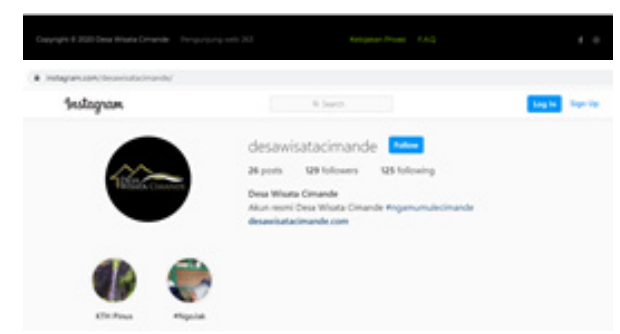

Figure 5. Links on the website (internal links)

On cimande tourism village website some links do not work properly. This is because of the incomplete information provided so that when the link is clicked access to the link is not available. Thus the repair of the link and its structure should and should be repaired or updated.

\section{Banners}

As is the use of banners on print forms. Banners on the website are also used as promotional media that can attract visitors to a website. Website banners can also create a certain impression of the products displayed. On cimande tourism village website, there is no banner on the website either banner about cimande village pro- 
ducts or products from other commercial businesses.

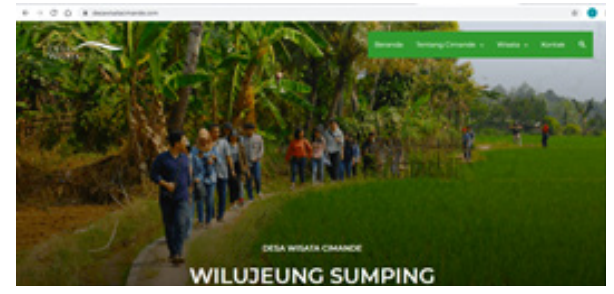

Figure 6. Home website

\section{PR Online}

Cimande Tourism Village website provides online public relation $(\mathrm{PR})$ in the form of email and phone (Figure $\mathrm{x}$ ). Visitors can ask the manager via email or phone that is already available on the Contact page of the website. However, online PR is classified as unresponsive. This is because there are no special officers who can answer all questions from visitors. The manager has not been able to provide officers to monitor the website every day. In addition, the provision of funds for internet quota is also not available.

On the website there is also a question and answer page or better known as Frequently Asked Question (FAQ). However, this page is not well populated so the page found is a $\mathrm{Q} \& \mathrm{~A}$ in a foreign language. In other words, the FAQ page is still the original version of the system and has not been changed by the manager. Other indicators of online PR are the news section, chat forums and online polls not found on the website of Cimande Tourism Village.

FREQUENTLY ASKED QUESTIONS

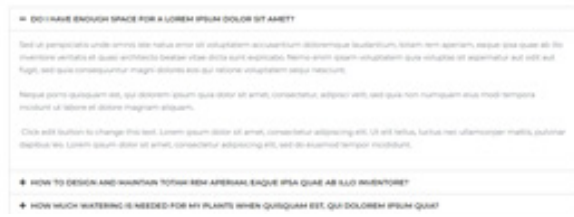

Figure 7. Website FAQ page

http://ojs.unud.ac.id/index.php/eot

\section{Element from Marketing E-mail}

On the website, e-mail can be used as a question-and-answer medium and product offering. But until now there have been no questions of visitors through the email. Managers also haven't used email as a medium to offer their products to specific agencies.

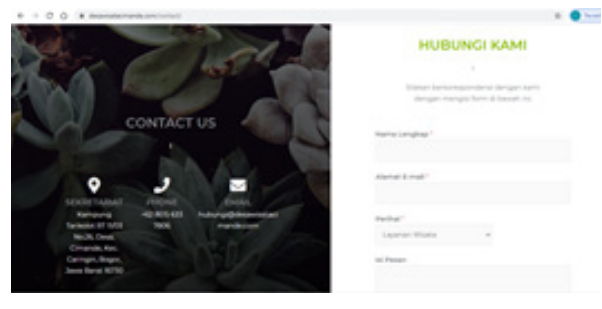

Figure 8. Contact Page

In the contact section of the website is also listed the address and phone number of the manager. However, the address and phone number have not been updated to date so it cannot be used and cannot be used as a reference in seeking information by website visitors.

\section{Rank}

Until now, the manager has not displayed the number of visitor visits to cimande tourism village area. This is because there are still a lack of visits so it is considered less impactful if displayed on the website. In addition, ranking indicators from the origin of visitors is not a priority for website utilization. The manager prioritizes the website as an information medium so that it is expected that visits to Cimande Tourism Village can continue to exist.

Based on the results obtained then the components of the website have not all been fulfilled properly. Of the 10 indicators observed, at least 5 indicators have been fulfilled by the website manager of Cimande Tourism Village Completeness of website dimensions can be seen in Table 3 .

The manager has attempted to make cimande tourism village website has a complete website component. However, 
Table 3. Website Dimensions

\begin{tabular}{ll}
\hline Dimension & Criteria \\
\hline $\begin{array}{l}\text { Visibility and search ranking engines } \\
\text { b. Rankibility }\end{array}$ & $\begin{array}{l}\text { Avaliable } \\
\text { Google }=16 \\
\text { Yahoo }=1\end{array}$ \\
& Bing $=1$
\end{tabular}

Source : Research Data, (2020)

due to the absence of special officers in managing the website every day and the lack of sufficient funds for the availability of the website, the manager still relies on the available website only. Therefore, the author recommends that managers work with other institutions or institutions to meet human resources needs in improving knowledge and skills related to the promotion of especially websites. In addition, the manager can also ask the relevant institutions or institutions to cooperate in the promotion activities of Cimande Tourism Village.

\section{CONCLUSION}

Cimande Tourism Village conducts promotional activities in the form of public relations and publicity and direct marketing. Research shows that Cimande Tourism Village website has a fairly good level of visibility by using search engines namely Google, Yahoo and Bing. Promotional techniques are carried out by linking information related to tourism, namely information about the activities of Cimande
Tourism Village itself. Online public relations are not yet available. Email websites are available even though they are still minimal in use. The manager has not recorded the visitors so the ranking related to the visitor does not exist.

\section{ACKNOWLEDGMENTS}

We would like to express our appreciation and thank you to RISTEK-BRIN (Kementerian Riset dan Teknologi / Badan Riset dan Inovasi Nasional) of Indonesian Republich who give us support in financing this research, to Sekolah Tingi Pariwisata Bogor (STP Bogor) which give us change in doing this research in Cimande Tourism Village.

\section{REFERENCES}

Andri (2009) 'Pengaruh Penggunaan Search Engine, E-mail Dan Mailing List Terhadap Kualitas Informasi Yang Dihasilkan Dalam Lingkungan Universitas Bina Darma Palembang', e-ISSN 2407-392X. p-ISSN 2541-0857 
Sriwijaya Journal of Information Systems, 1(3), p. 130215.

Anshar, A. and Batubara, R. P. (2019) 'Analisis Penerapan Prinsip Ekowisata Di Kebun Raya Bogor', Bogor Hospitality Journal, 3(2), pp. 1-8.

Batubara, R. P. (2020) 'Strategi Pengembangan Oukup sebagai Ekowisata Kesehatan Kabupaten Karo', Jurnal Ilmiah Pariwisata, 25(2), pp. 121-132.

Fernández-Cavia, J. et al. (2014) 'Web Quality Index (WQI) for official tourist destination websites. Proposal for an assessment system', Tourism management perspectives, 9, pp. 5-13.

Handayani, I., Febriyanto, E. and Shofwatullah, M. (2019) 'Optimalisasi visibilitas situs iLearning Journal Center (iJC) Pada Mesin Pencari Berbasis Search Engine Optimization (SEO) On Page', Sains dan Teknologi Informasi, 5(1), pp. 27-35.

Joshi, P. (2012) 'A Stakeholder Networking for Sustainable Rural Tourism Development in Konkan Region of Maharashtra State (India)', Reseach Paper, 1.

Ku, E. C. S. and Chen, C.-D. (2015) 'Cultivating travellers' revisit intention to etourism service: the moderating effect of website interactivity', Behaviour \& Information Technology, 34(5), pp. 465-478.

Marpaung, H. and Bahar, H. (2002) 'Pengantar pariwisata', Bandung: Alfabeta.

Noviyanti, S. (2014) 'E-Tourism: bentuk promosi pariwisata Indonesia selan- jutnya', Kompas Gramedia, Jakarta.

Pearce, D. (1995) 'Tourism a Community Approach. 2nd: Harlow Longman'. Washington. DC (US): Island Press.

Santoso, D. B. (2009) 'Pemanfaatan Teknologi Search Engine Optimazion sebagai Media untuk Meningkatkan Popularitas Blog Wordpress', Dinamik, 14(2).

Sari, D. P. (2017) 'The Process of Making Tempe Benguk as Tourist Attraction in Kulon Progo Yogyakarta', E-Journal Of Tourism, pp. 78-84.

Sari, D. P. (2018) 'Apakah Ada Peranan Aktivitas Wisata Dalam Peningkatan Ekonomi Daerah Di Kota Bogor?', Barista: Jurnal Kajian Bahasa dan Pariwisata, 5(1), pp. 12-22.

Sari, D. P. (2019) 'Motivation towards Inbound Tourism: A Study of Middle East Tourist', E-Journal of Tourism, pp. 235-251.

Sebastia, L. et al. (2009) 'e-Tourism: a tourist recommendation and planning application', International Journal on Artificial Intelligence Tools, 18(05), pp. 717-738.

Stankov, U., Ćurčić, N. and Dragićević, V. (2010) 'Assessment of forms and extent of tourism web promotion in Serbia', Journal of the Geographical Institute" Jovan Cvijic", SASA, 60(1), pp. 57-68.

Sugiarti, R. (2008) Geografi Perdesaan Sebuah Antologi. Yogyakarta: IdeAs Media. 